\title{
Social Sustainability
}

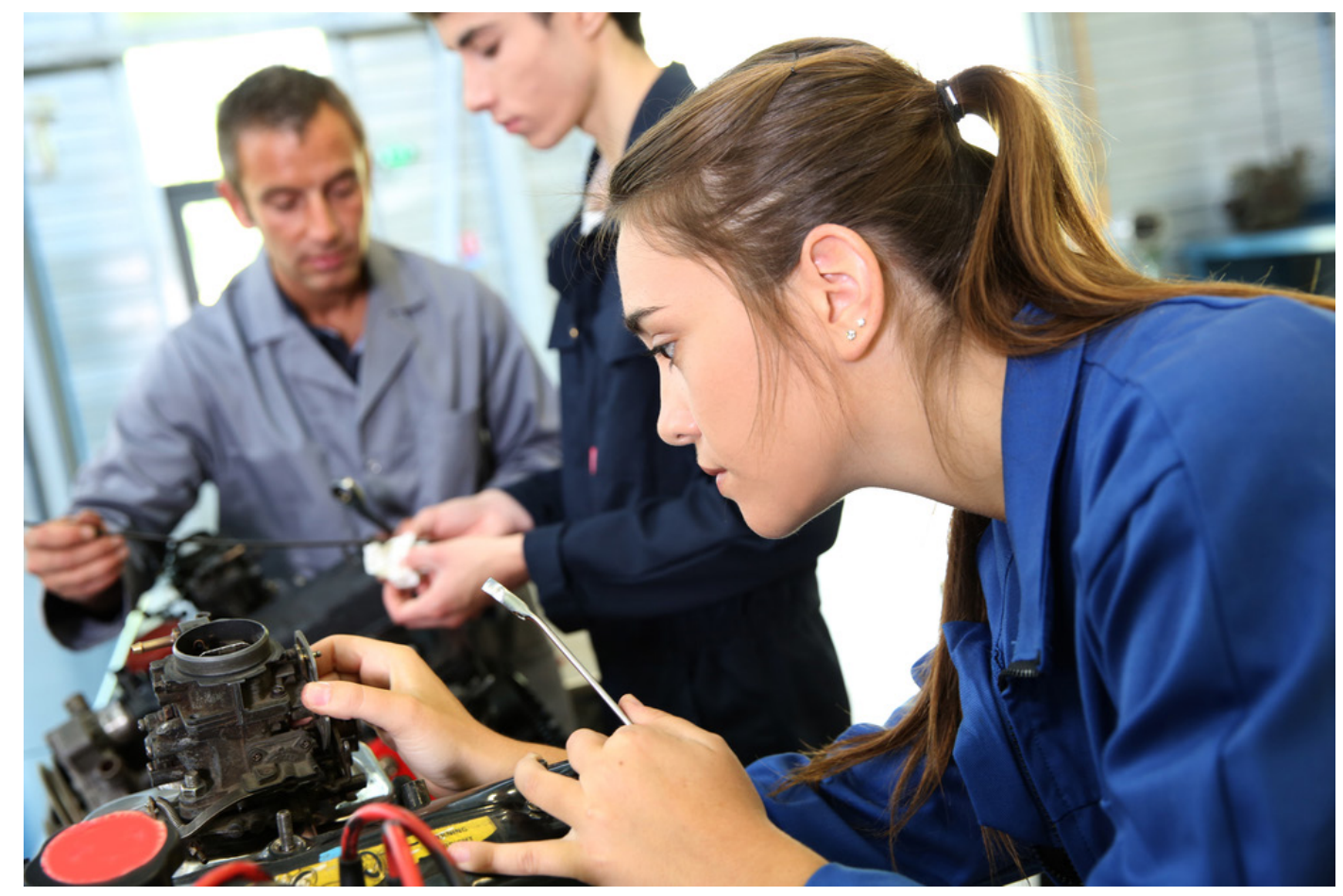

Image reproduced with permission from goodluz/Shutterstock.com. All rights reserved.

\section{THIS CHAPTER PROVIDES:}

- The place of social sustainability in the context of sustainability as a whole.

- A systems view of how individuals, industries and society relate to each other.

- Design concerns when addressing the well-being, performance and retention of future workforce.

How to cite this book chapter:

Berlin, C and Adams C 2017 Production Ergonomics: Designing Work Systems to Support Optimal Human

Performance. Pp. 241-258. London: Ubiquity Press. DOI: https://doi.org/10.5334/bbe.m. License: CC-BY 4.0 


\section{WHY DO I NEED TO KNOW THIS AS AN ENGINEER?}

Sustainability - in any form - is about enabling the present generation of people to live well and fulfil their goals, without threatening the possibility of future generations to do the same. This idea can be scaled up and down, from a lofty global socio-economic perspective all the way down to what goes on in the interaction between a human and a machine. One thing is certain - to understand sustainability, we must understand that its challenges emerge primarily from an interlinked, global and systemic view, which sometimes makes it challenging to apply to isolated sub-system concerns. But it is possible!

The common understanding of these developments remains low. Since Western economies have periodically (and recently) experienced economic recession, the ghost of instable economy and high unemployment makes many people think that corporations are at liberty to treat workers as expendable. This, however, cannot remain a viable business model in the long run, because competitiveness, innovation and increased productivity (not to mention a stable society) can only be achieved with a healthy, motivated workforce willing to stay longer and develop.

In light of this, the concept "social sustainability" becomes relevant to relate to. At the time this book is written, there is unfortunately little agreement in research about what the meaning and scope of social sustainability should be, leaving many companies and practitioners with the responsibility of defining what it means for themselves. For these reasons, the purpose of this chapter is to make the case for ergonomics and human factors as a means to achieve social (and economical) sustainability in production. With good knowledge of human needs and capabilities, engineers can address upcoming social challenges at the local as well as the macro level.

In the future it will remain important for an engineer to be able to persuasively argue for both short-term improvements and long-term supporting of human performance. Without social sustainability awareness, it will become difficult to communicate to other stakeholders that the best workplaces for human beings are part of a sustainable development. To achieve that, you must become aware of how your design skills can align with helping the productivity, quality and efficiency of experienced aging workers high, while at the same time attracting a new generation of workers who will see a positive and attractive future in the places that you design for them.

Furthermore, when you graduate, your ability as a prospective job applicant to identify socially sustainable companies may not only leverage your career - it may also inspire more companies to start taking action towards social sustainability, when they realize that this is the long-term way to attract the best future talent, keep their business operations running long-term and retain a skilled and knowledgeable workforce. 


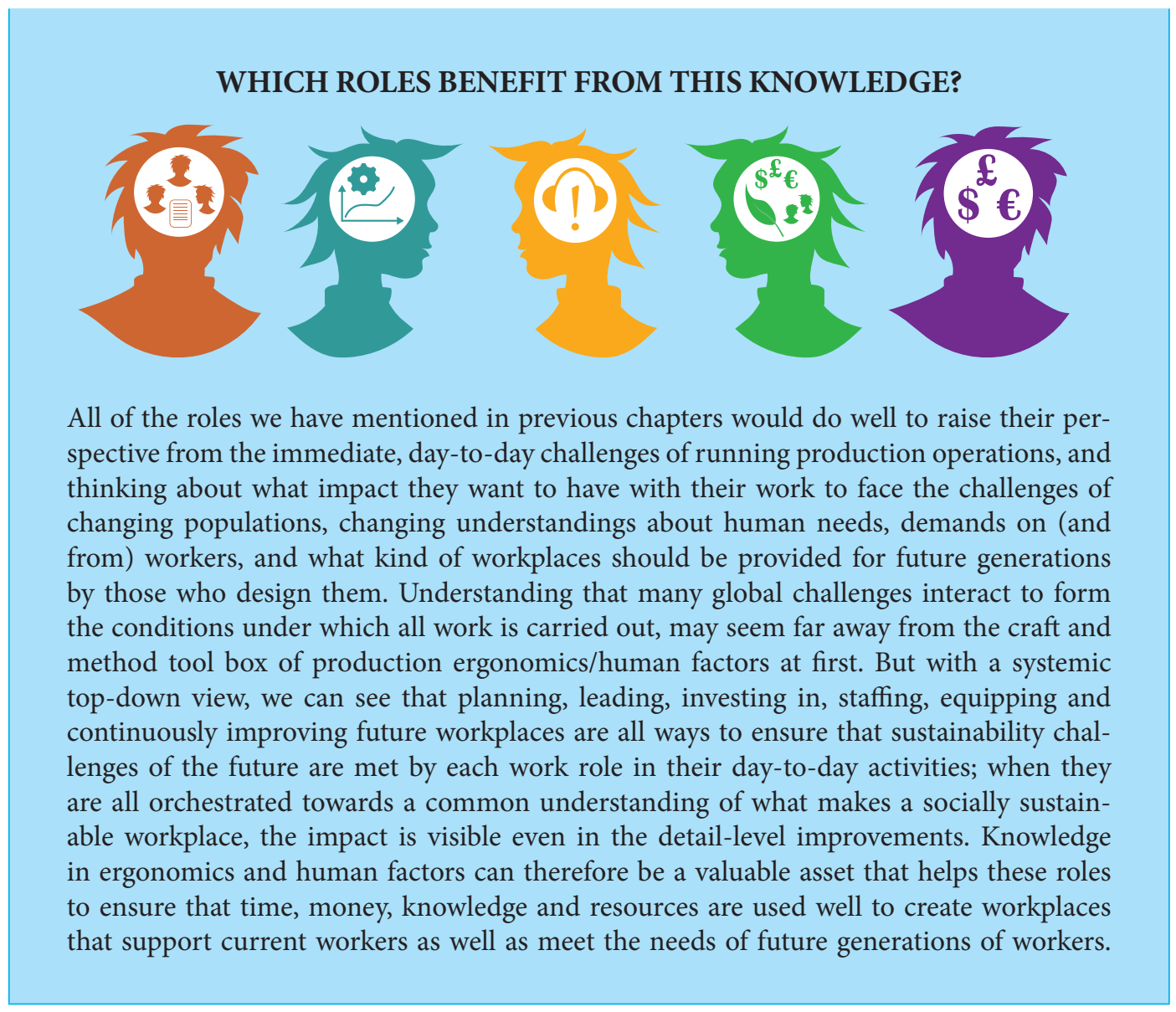

\subsection{Upcoming societal challenges}

\section{Demographics - who are the future workers?}

Demographics - the measurement of populations by number of people - are about to present the working world with a challenging future. Consider the curve shown in Figure 13.1. This chart shows the number of people (sub-divided into age segments) that made up the population of Europe in the year 2012, with numbers including both people being born and migrating into Europe. To the left of the chart are children and young people who have not yet entered the job market, and on the far right are the people nearing retirement.

The majority of those employed in European production industry are between the ages of 35 to 64. As time passes the bars gradually move further and further to the right of the chart as people age (the ones on the far right decrease in height as more elderly people pass away). Typically, the number of people in each age segment does not change much. At the same time, the shape of the silhouette shows the typical recruitment pattern of production industry: the youngest employees are around 


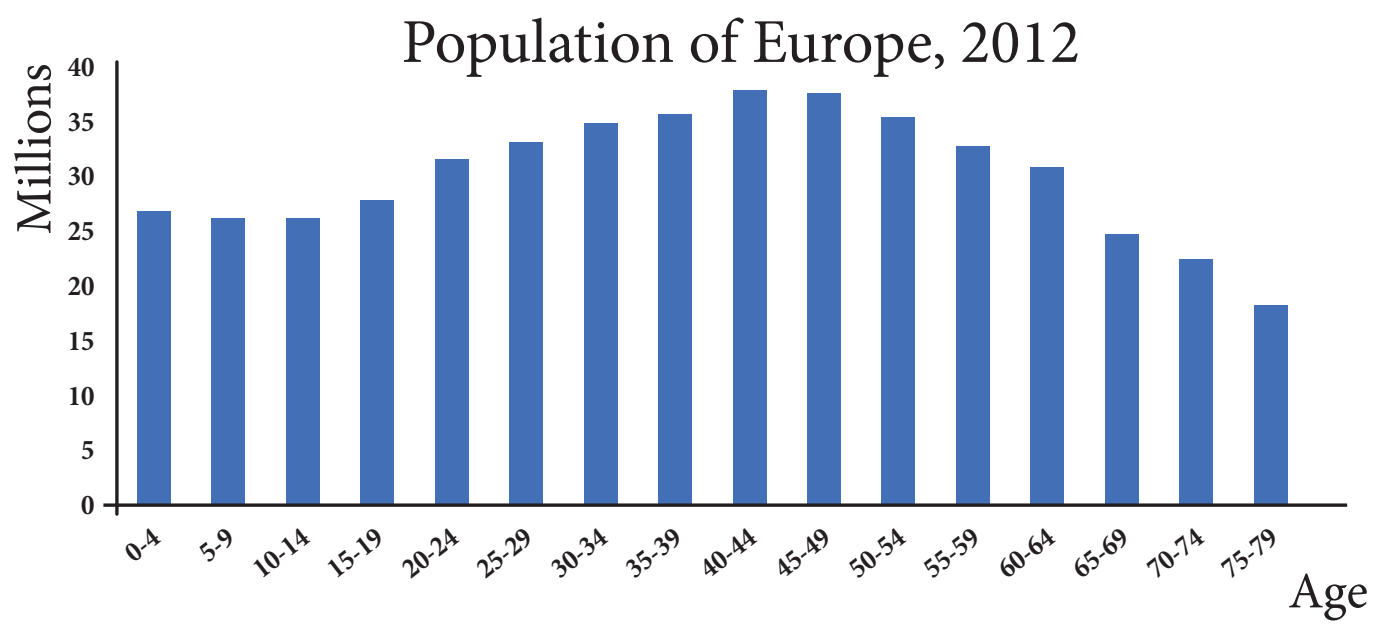

Figure 13.1: The population of Europe in 2012 for different age groups (depicted as bars) according to Eurostat (2012). Typically, the demographics of the industrial workforce has the same silhouette, with the majority being between the ages of 35 and 64 .

Image by C. Berlin, based on graph in Berlin et al. (2013).

20 to 25 years old, the majority who stay employed are 35 to 64 , and retirement starts around the age of 65 and tapers off to about 74 . However, this presents a problem for the future: the sheer numbers of currently employed people aged 40 to 64 are proportionally much more numerous (by tens of millions) than the young people available to replace them, meaning that there is a gap between the number of employed people headed for retirement, and the number of people available to take over their work. Even though this particular chart shows a slight trend change to the left, indicating that more children are being born in Europe, the difference in numbers is still likely to cause recruitment problems, starting in 2020 and continuing into the coming decades. This means that we are experiencing a time in history where the populations in many countries are aging; the proportions of old to young are becoming unbalanced.

At the time this book is written, serious world events in the Middle East have sparked a dramatically increased migration of refugees into Europe, which has been a major transition both at the societal and individual levels; some actors in society choose to frame this as a potential opportunity. If the industrial sector is to continue being a stable source of jobs, productivity and income, these actors argue, integration of newcomers into European society and the labour market is essential. If there is a possibility for them to become employed and trained, their presence will be possible to turn into part of the solution to Europe's demographic challenges. Without functional solutions for labour and educational integration, societal structures may be strained by people who are not able to earn a livelihood due to lack of inclusion, and the lack of staffing in European industries will remain an unsolved challenge. Solutions to these broad challenges must primarily be political and legislative, but workplaces can also prepare for inclusion of new employees - for example with smart communications technology, picture-based instructions, knowledge databases and mentorship between senior and junior employees. 


\section{Challenges in countries with aging populations}

As populations grow older as a whole, societies face the problem of having decreasing numbers of people working in value-creating jobs that allow export (i.e. production), thereby bringing income and supporting the nation's economy. Another expected development is that the projected number of old people who will require health care will demand that a greater proportion of young people than today work in the eldercare sector. In some countries, an aging population requires that fewer young people will be economically supporting more old people; this may rather soon become the case in e.g. Germany, Italy and China, where the One-child policy of 1979 (Beech, 2013), which previously limited Chinese families to having just one child, was recently phased out (in 2015) as Chinese government officials realized the detrimental and destabilizing effects of having a large aging population and few young people available to enter the labour market.

Figure 13.2 shows the projected changes in age structure between 2010 and 2030 for the German population aged 20 to 64, according to Germany's Ministry of the Interior in 2012.

All in all, this type of demographic imbalance may cause the production industry problems in the future, which can be handled in two ways: the first is to retain older workers until a higher retirement age, and the other is to actively broaden the recruitment pool for new workers. The first approach requires workplaces to be designed to support the needs and limitations of the elderly, so that any age-related impairments (like sight, hearing, and technological unfamiliarity) will have a minimal effect on productivity, and that the know-how of the oldest workers can be put to good use. The sec-

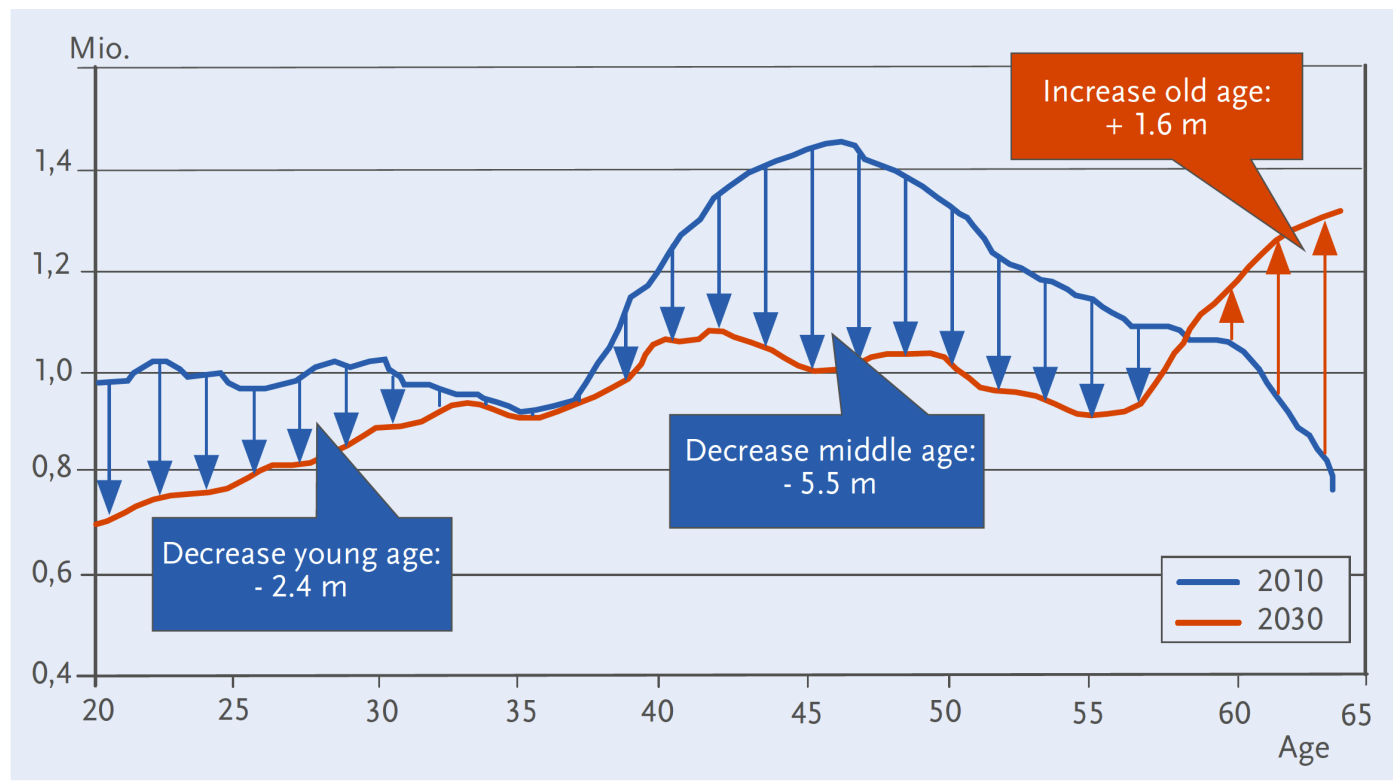

Figure 13.2: Projected differences in the German population's age structure between 2010 and 2030 (Fig. 1 from p. 3 of Richter, Bode and Köper, 2014).

Image reproduced with permission from G. Richter and B. Köper / Bundesanstalt für Arbeitsschutz und Arbeitsmedizin (BAUA). All rights reserved. 
ond approach should not be interpreted merely as attracting a younger workforce; using adaptable design of workplaces, equipment, tasks, training and instructions, it is possible to widen recruitments to a more diverse work pool, including underrepresented genders, "outlier" employees (see Austin and Sonne, 2014) and previously overlooked cultural groups, as well as both older and younger new recruits.

\section{Unemployment}

A common counter-argument to the challenges presented above is that Europe has been struggling for a long time with high unemployment rates, particularly for young people. This has been the case for a long enough time to make some people accept this as a universal, unchanging truth: that there will always be more available workforce than jobs. This view tends to foster a cynical outlook that companies are at liberty to treat their workforce badly, as the job market is supposedly full of replacements if they choose to quit, or to move production to low-cost labour countries. Although development suggests that this is changing, it is useful to first define what is meant by unemployment and similar related terms, as this can sometimes cause confusion. Table 13.1 presents unemployment-related terms that may be useful to distinguish between.

These definitions suggest that it is important to differentiate between reasons for not being available to workforce when using the term "unemployed". However, none of the terms in Table 13.1 reflect

Table 13.1: Unemployment-related terms according to ILO (International Labour Office), Eurostat and OECD (combined definitions).

\begin{tabular}{|c|c|}
\hline EMPLOYED & $\begin{array}{l}\text { People above a specified age who at the time of being surveyed are engaged in paid } \\
\text { employment or self-employment (depending on the specific survey, this may some- } \\
\text { times include or exclude part- time employed). Employment (and unemployment) is } \\
\text { normally reported for people between } 15 \text { to } 64 \text { years of age. }\end{array}$ \\
\hline UNEMPLOYED & $\begin{array}{l}\text { People above a specified age, who at a certain point in time are: } \\
\text { - not engaged in paid employment or self-employment } \\
\text { - available to start working with short notice, and documented as having been } \\
\text { seeking employment (paid or self-employment) during a specified period leading } \\
\text { up to the point of being surveyed }\end{array}$ \\
\hline LABOUR FORCE & $\begin{array}{l}\text { The number of people employed plus unemployed (i.e. who are able and available to } \\
\text { work, and may or may not be doing so) }\end{array}$ \\
\hline $\begin{array}{l}\text { UNEMPLOYMENT } \\
\text { RATE }\end{array}$ & Unemployed people as a percentage of the labour force. (OECD, 2014) \\
\hline $\begin{array}{l}\text { NOT CURRENTLY } \\
\text { ACTIVE } \\
\text { POPULATION }\end{array}$ & $\begin{array}{l}\text { Persons who are currently not in the labour force, due to any of the following reasons: } \\
\text { - attending an educational institution } \\
\text { - performing household duties } \\
\text { - retiring on pension or capital income } \\
\text { - other reasons, including disability or impairment (OECD, 2014) }\end{array}$ \\
\hline STUDENT & $\begin{array}{l}\text { A person regularly attending an educational institution for systematic instruction at } \\
\text { any level of education; not classified as usually economically active (OECD, 2014) }\end{array}$ \\
\hline
\end{tabular}


the situation of employers who are unable to find respective employees with a suitable skill set. The mismatch between available workforce and desired skill levels requested by companies has been identified is a major contributor to the massive youth unemployment of the European Union (Mourshed et al., 2014).

\section{Skills gap}

Regarding unemployment in Europe, and indeed the rest of the world, the notion that future demographics will result in greater demand for younger workers may be a heartening message, but it needs to be taken with a pinch of salt. What is happening is that the nature of work is also changing, thanks to technology and new knowledge. This means that in spite of the imbalance between young and old, many young people will be unskilled labourers who will continue to be in lesser demand, according to Dobbs et al. (2012).

For production, this means that many jobs are transitioning from thoughtless, menial labour into creative work requiring skill and problem-solving capabilities. The term "skills gap" implies that there is a mismatch between future work roles and the competence of the available workforce today. This gap can be solved in two ways: one is to change the nature of national education at large to prepare young people for work in skilled environments. The other is for individual companies to provide education and training themselves, targeting new employees who do not yet have the required skill set, but are willing to learn and work in that industry. Specific steps towards a better transition from Education to Employment (E2E) have been suggested by McKinsey Center for Government (Mourshed et al., 2014).

\section{Business as usual? Staying competitive in the future}

For most industries, from both international and multinational perspectives, what remains a central priority is business and profitability. However, the recognition of the changing times and demographic developments has made it apparent in many countries that future business is dependent on staying innovative and delivering actual high-value products that can be exported. This is becoming evident at policy level in many places in the form of "re- industrialization" initiatives; this denotes the return of manufacturing operations that were previously moved overseas, back to their company's country of origin in order to strengthen economic resilience and ensure jobs and disposable incomes in that country (Foresight, 2013; Westkämper, 2014). In September 2012, the United States Department of Commerce (2012) released the campaign "Make it in America", a manufacturing strategy geared at making more products in America, creating high-skill high-wage jobs and increasing competitiveness, innovation and exports. Similar European goals are being addressed by the Horizon 2020 funding initiative (European Commission, 2014) "Factories of the Future", which supports "manufacturing industry in the development of new and sustainable technologies" in order to keep manufacturing jobs in Europe and addresses many of the aforementioned social sustainability challenges. The drive to be industrially competitive is also visible in the Indian government's campaign "Make in India" (Make in India, 2015), launched in 2014 to convince both multinational and domestic corporations to manufacture products in India, boosting India’s domestic job creation and skills enhancement. The movement is also evident in Europe; Swedish production enterprises with international production operations have taken action to bring some production back from foreign countries to Sweden. Two main reasons are cited: the first is that high-level consumer goods sectors benefit from having their 
production close to product development headquarters, and the second is that production should be close to the customers; for Sweden, the main market tends to be the European Union.

\section{Future needs, wants and expectations}

It is important for companies to remember that being an attractive workplace is not a goal in itself, but a means to overcome the challenges of the future, while staying more productive, competitive and profitable.

Returning our attentions to the workforce, it is important to recognize that future needs, wants and expectations are going to be different in the future for different demographic subgroups (such as young, elderly, women, people with families, people at different education levels, etc.). It will become necessary for companies to identify and address those future needs, wants and expectations in order to attract a younger and more diverse workforce, while at the same time supporting the aging population so that the knowledge balance and the company can be retained. At the same time, what is considered a good life and a successful career is a question of societal values, which change over time. For example, according to Accenture (2013), educated women rate work-life balance as a higher priority than salary when seeking a job. Another study by Halkos and Bousinakis (2010) showed that productivity at work decreased when there were stress-related impacts on family life.

People born from the 1980s and later are frequently referred to as "digital natives", due to their life-long exposure to human-computer interfaces and expectations of a high degree of digital connectivity and free access to information. These expectations on technology are coupled to high levels of familiarity with handling interfaces, which perhaps cannot be expected to the same extent from older workers. Furthermore, Karazman et al. (2000) state that a sustained interest in their work is essential to keeping elderly workers.

The business developments of the last couple of decades have displayed behaviours of young professionals "hopping" between careers at different companies, spending just a few years at each position. While this has long been considered beneficial to career development, is hardly beneficial to companies who repeatedly have to re-recruit personnel to replace employees who leave, using up precious resources of time and money and losing valuable experience and competence.

One of the major reasons for creating more "staying power" in a company is to create good conditions for innovation. Innovation is widely cited as the most important way to competitiveness for future industries, but it is dependent on the creativity of humans and of the humans staying at a company long enough to develop skills and knowledge that will make innovative ideas relevant for their specific industrial sector. Although there is a widespread notion that robots and automation still remain a threat to the continued importance of humans in production, more industry leaders are beginning to realize that robots do not have the ability to be innovative.

\subsection{Sustainability concepts}

\section{Sustainability history}

The concept we now know as sustainability saw the first light of day in 1987, when the term Sustainable Development was famously defined by the United Nations World Commission on Environment and Development (WCED) as: 
"Development that meets the needs of the present without compromising the ability of future generations to meet their own needs."

(WCED, 1987)

This definition came from the commission's report, which is familiarly called "The Brundtland Report" after its chair Gro Harlem Brundtland. At the time, focus was primarily on environmental conservation and responsibly ensuring the continued improvement of economic living standards for developing countries, while conserving the world's natural resources. However, in the years that followed, the wide, abstract concept of sustainable development was elaborated along three tracks:

- Economic: profitability, business growth, meeting market demands

- Environmental: planet, environmental resources, natural heritage

- Social: people, social justice, equity and equal opportunities

The term Triple Bottom Line (Elkington, 1998) gained popularity when a popular book on "green business" raised awareness among business managers about how the lifespan of their businesses could be extended if they considered not only the monetary bottom line, but also environmental and social impacts. A catchier, well-known phrase expressing the TBL concept is "People, Planet, Profit". However, the original TBL term was written from the perspective of making progress in "green business" and placed the "people" focus more on social justice.

\section{Glossary of important terms and concepts}

\begin{tabular}{|c|c|}
\hline $\begin{array}{l}\text { SUSTAINABLE } \\
\text { DEVELOPMENT }\end{array}$ & $\begin{array}{l}\text { As defined in the Brundtland report (WCED, 1987): "Development that meets } \\
\text { the needs of the present without compromising the ability of future generations to } \\
\text { meet their own needs." }\end{array}$ \\
\hline SOCIAL EQUITY & $\begin{array}{l}\text { As defined by the } 1996 \text { US President's Council on Sustainable Development } \\
\text { (NASA, 1996): } \\
\text { "Fair and impartial access to social or public services regardless of economic or } \\
\text { social status." } \\
\text { Alternative definitions include access to livelihood, education, resources, partici- } \\
\text { pation in society and self-determination. May include gender aspects. }\end{array}$ \\
\hline SOCIAL EQUALITY & Often considered equal to social equity. \\
\hline $\begin{array}{l}\text { TRIPLE BOTTOM } \\
\text { LINE }\end{array}$ & $\begin{array}{l}\text { As defined by Elkington (1998): a business-centred approach to the social, envi- } \\
\text { ronmental and economic sustainability tracks, the idea is to prepare business on } \\
\text { three "accounts": those of "people, planet, profit". } \\
\text { TBL has been criticized because of its basic capitalist assumptions and corporate } \\
\text { focus, and the fact that social and environmental sustainability cannot be readily } \\
\text { translated to the "cash" level of economic sustainability. }\end{array}$ \\
\hline $\begin{array}{l}\text { SOCIAL } \\
\text { RESPONSIBILITY } \\
\text { (ISO) }\end{array}$ & $\begin{array}{l}\text { As defined by the standard ISO } 26000 \text { (ISO, 2010): how businesses/organizations } \\
\text { can operate in the socially responsible way in the society and environment in } \\
\text { which they exist, by acting in an ethical and transparent way that contributes to } \\
\text { the health and welfare of society. }\end{array}$ \\
\hline
\end{tabular}




\begin{tabular}{|l|l|}
\hline $\begin{array}{l}\text { CORPORATE } \\
\text { SOCIAL } \\
\text { RESPNSIBILITY }\end{array}$ & $\begin{array}{l}\text { As defined by Holme and Watts (2000): } \\
\text { "a continuing commitment by an organization to behave ethically and contribute } \\
\text { to economic development, while also improving the quality of life of its employees } \\
\text { ABBREVIATED CSR) }\end{array}$ \\
$\begin{array}{l}\text { (and their families), the local community, and society at large." } \\
\text { As defined by the United Nations Environment Programme (UNEP/Setac, 2009): } \\
\text { "(..) companies should, at the very least, be held to international standards of } \\
\text { human and workers' rights, and that they should consider environmental output } \\
\text { regulations when making corporate decisions." } \\
\text { Also referred to as "Corporate Social Performance" (Carroll, 1979). }\end{array}$ \\
\hline HUMAN CAPITAL & $\begin{array}{l}\text { A popular but slightly debated term that conveys the economical view that human } \\
\text { beings are an asset in economical systems, partaking in labour and creating value } \\
\text { by means of competence, knowledge, cognitive abilities, creativity and personal } \\
\text { attributes that make them a valuable human resource. } \\
\text { The term is ambiguous because some schools of thought associate it purely with } \\
\text { assets in the form of education and cognitive skills, while others do not. }\end{array}$ \\
\hline SOCIAL CAPITAL & $\begin{array}{l}\text { This concept is centred around social networks between people built on trust, } \\
\text { reciprocity and common understandings that allow a society to function through } \\
\text { cooperation between groups. Defined by the OECD as "networks together with } \\
\text { shared norms, values and understandings that facilitate co-operation within or } \\
\text { among groups" (Healy and Côté, 2001). }\end{array}$ \\
\hline
\end{tabular}

\section{Social sustainability definitions}

From a research perspective, there has not been much convergence in literature on the scope or focus of the term social sustainability to date. This makes it difficult to state a universally accepted definition of what social sustainability is, since the angle of which human-related problem to solve often determines the scope. Quite often, different fields of research (including the one of production ergonomics) will decide quite arbitrarily what level of societal inclusion to zoom in on; at present, explicitly stating this range of scope is the best-known way to relate different conceptualizations of social sustainability.

There are also overlaps between social issues and the other pillars of sustainability; for example in ethical sourcing of product materials, housing developments and eradication of world poverty. According to a recent social sustainability literature review by Vallance et al. (2011), some main aspects considered are "inter- and intra-generational equity, the distribution of power and resources, employment, education, the provision of basic infrastructure and services, freedom, justice, access to influential decision making for and general 'capacity building"'.

Colantonio (2009) of the Oxford Institute for Sustainable Development (OISD) has described some key themes of social sustainability (Table 13.2.). This shows that there is an on-going shift in the understanding of what social sustainability means, moving from human living standards and equity towards work, employment, integration and work-life balance. This reflects the recent focus on demographics-driven changes.

\subsection{The ecosystem of social sustainability}

In order to achieve lasting solutions, social sustainability initiatives need to be balanced from a number of different perspectives. It is important to realize that the concerns and priorities for different 
Table 13.2: Traditional and emerging key themes of social sustainability (Colantonio, 2009)

\begin{tabular}{|l|l|}
\hline TRADITIONAL & EMERGING \\
\hline - Basic needs, including housing & - Demographic change (aging and international migration) \\
- Education and skills & - Empowerment, participation and access \\
- Equity & - Identity, sense of place and culture \\
- Employment & - Health and safety \\
- Human rights & - Social mixing and cohesion \\
- Poverty & - Social capital \\
- Social justice & - Well-being, happiness and quality of life \\
\hline
\end{tabular}

stakeholders (individual prospective workers, current workers, their families, the company, the community surrounding it and the country as a whole) are tightly interconnected. A change for one stakeholder will affect all the others in terms of expectations, needs, motivations, behaviours (both collective and individual), regulations, infrastructure and values.

Figure 13.3 shows some examples of how the priorities of the individual, industry and society overlap and need to be balanced out in order to secure the right kind and amount of workforce for future

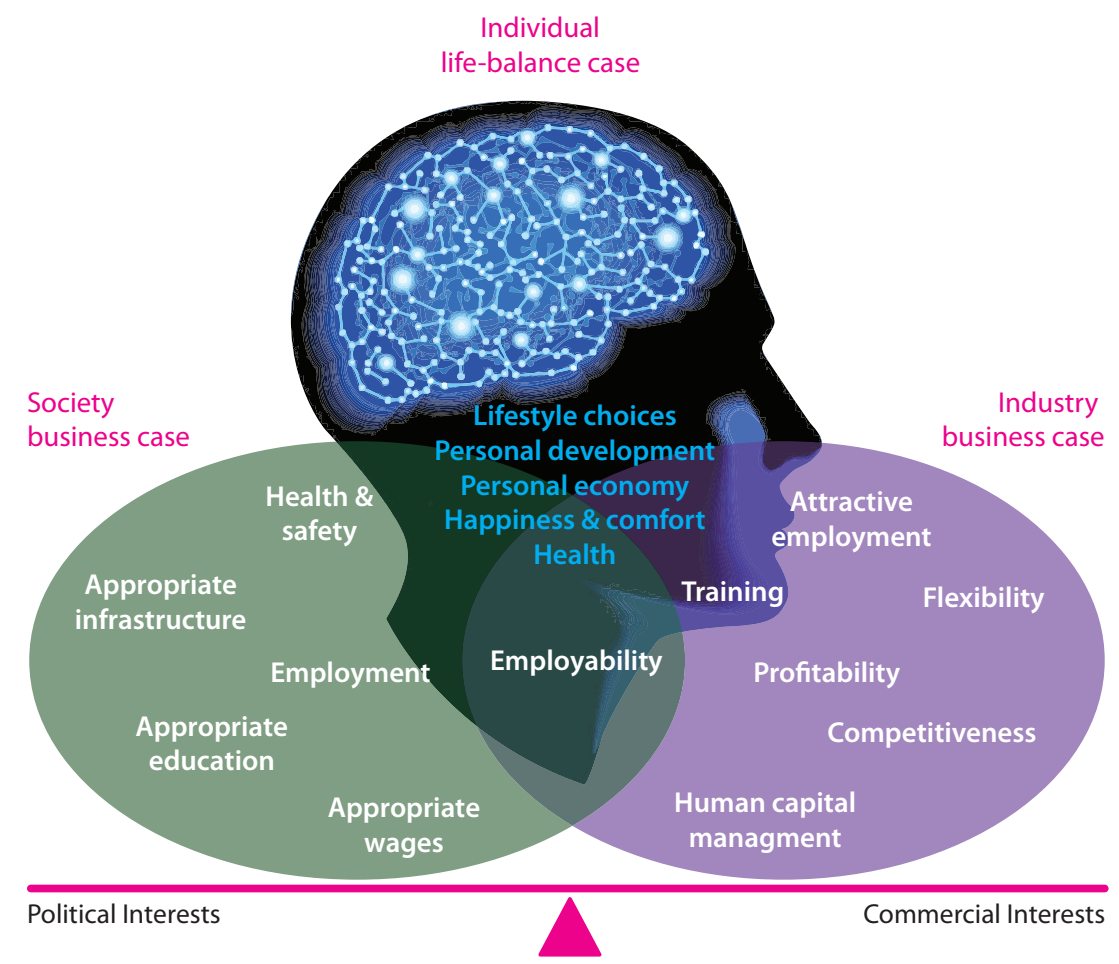

Figure 13.3: The ecosystem of social sustainability, which needs balanced solutions for the needs of the individual, industry and society (SO SMART, 2014).

Image by Vladgrain/Shutterstock.com, with modifications by Elisabetta de Bertti. All rights reserved. 
Table 13.3: Examples of social sustainability concerns at different levels.

\begin{tabular}{|l|l|}
\hline Individual & - Being adequately paid to maintain a satisfactory lifestyle \\
- Staying healthy, including a sound mental health \\
- Maintaining a healthy work-life balance \\
- Being provided with well-fitted, healthy and understandable workplaces and tasks \\
- Collaborating in a fruitful way with co-workers and management \\
- Developing skills and prominence in one's chosen vocation \\
- Learning and getting support for one's work tasks \\
- Having a purpose in one's social reference system \\
- Developing one's skills and career in one or more companies \\
- Having a safe position to care for family \\
- Having access to living quarters and ways to commute to work \\
- Making conscious choices about pay level and personal motivation (e.g. prioritizing high pay \\
or other motivational factors) \\
\hline - Being able to make sound business cases for workplace or organizational change \\
- Staying competitive in a global perspective by managing human capital and talent \\
- Retaining trained and skilled staff \\
- Demonstrating the economic benefits of reducing work-related discomfort, ill health and \\
absence both in direct and indirect costs \\
- Supporting the ability of entry-level staff to learn and perform tasks to a high level of quality \\
- Designing and building workplaces that ensure maximum safety, health and engagement \\
- Creating an exciting work environment and community at the workplace \\
- Offering and maintaining a steady level of employment for citizens \\
- Encouraging mobility of employable workforce (within and across countries) \\
- Providing adequate general education and training to support industries' need for \\
employable entry-level staff \\
- Decreasing the level of work-related injuries and ill health, avoiding costly economic damage \\
- Providing an attractive infrastructure for business
\end{tabular}

production. This balance is considered very important from a policy level, and this is highlighted by current initiatives by the European commission (European Commission, 2014.).

Table 13.3 shows examples of some concerns that may affect decisions at individual, company and society levels. It is also important to remember that the decisions at each level are made with respect to different time perspectives. For society, initiatives often need to be made with long-term stability in mind, in contrast with quarterly or yearly goals for a company. For the individual, the timeframe of priorities and decisions will vary, between the short and long-term, depending on personal changes in life (such as starting a family, getting injured, relocating, etc.).

\subsection{Social sustainability for work and workplace design}

For our purposes of production ergonomics and work design, it can be said that social sustainability concerns the ability of present generations to earn a living and be part of a community they contribute to economic growth (productivity and societal growth) while enjoying well-being and having fair 
opportunities for remuneration, education, personal development and work-life balance. In this way, the focus is placed on the overlap between social and economical issues. This is an important active choice in order to focus social sustainability action on the future challenges for production companies that we described in the first section of this chapter. To phrase this in terms of our design problem, the shift of focus goes from "decent jobs" to "attractive jobs", in order to attract the most talented work pool and stay competitive.

From that company perspective, social sustainability will then focus on recruiting, keeping and developing employees, so that their personal development benefits their own well-being and the competence level in the company. The two are interconnected, in the sense that personal development contributes positively to well-being. Companies would do well to communicate their focus on this connection in their outwardly communicated vision, company values, activities and benefits or services offered to employees.

\subsection{Design for social sustainability}

It may be useful to formulate a social sustainability mission statement for any work or workplace design, to guide more detailed design decisions. The authors of this book propose the following mission statement:

\section{Design work and workplaces to achieve the following:}

1) Attract and stimulate individuals.

2) Integrate and support groups.

3) Retain and give recognition to teams.

\section{The role of engineers in social sustainability}

As engineers, you will find that you are frequently trusted with the mandate to improve and make changes to a workplace. If you are an engineer who is aware of social sustainability and the many benefits that can be reaped from actively designing towards that goal, you have many ways to communicate that awareness, both in what you say and in what you do:

- Carry out work task improvement in a structured manner (analysis and solution building).

- Know which physical, physiological and psychosocial risks to remove from work systems, both the "slow" ones and the sudden ones.

- Know how to provide support for difficult cognitive processes that future operators face.

- Argue for improvements by demonstrating that a human-centred solution can remove many "hidden" costs and productivity barriers.

- Choose suitable equipment from the perspective of a worker who is exposed to loading.

- Know the value of letting workers give input (both for getting ideas and getting acceptance).

- Learn about human needs (see Chapter 6) and think of ways that your engineering skills can fulfil them.

- Speak a language that management understands. 


\section{Study questions}

\section{Warm-up:}

Q13.1) How does the WCED define Sustainable Development?

Q13.2) What is meant by the term CSR?

Q13.3) Name three challenges faced by current European manufacturing companies regarding future staffing.

Q13.4) How is the retention of staff in a company impacted by regularly training them?

Q13.5) In what ways can inclusive workplace design contribute to a workplace being more socially sustainable?

\section{Look around you:}

Q13.6) Look at the "Emerging" column in Table 13.2; can you think of ways that current employers might take action to address the concerns in that column?

Q13.7) Can you think of a company that is well-known for wanting to attract a young and talented workforce? List what kinds of incentives they have in place to a) ease worklife balance, b) train and develop their staff and c) support and encourage innovativeness and creativity.

\section{Connect this knowledge to an improvement project}

- Identify the "future generations" perspective in your workplace improvement projects and try to make a statement about the projected impacts on current and future workers in the long term. What actions can be implemented to ensure that they are protected and motivated to continue working there?

- Reflect on the impacts on individuals, the work team, the company and society in different improvement projects. How far do the effects of a workplace improvement spread?

- In any project, review the overviews of human needs described in Chapter 6 and see if fulfilling them may give rise to new ideas for improvement potentials.

\section{Connection to other topics in this book:}

- A socially sustainable workplace is a very wide concept, so using the knowledge from all of the preceding chapters can contribute to its fulfilment. However, it is important to apply a holistic and systematic approach to avoid optimizing one aspect possibly at the expense of others, so it is important to understand how the different areas of ergonomics overlap and interact with each other. 
- The focus on teams, stakeholders and worker involvement in social sustainability discussions make the topics of psychosocial factors and worker involvement (Chapter 6), economic aspects of ergonomics (Chapter 11) and the relation of different stakeholders to the different areas of knowledge (the "roles" section at the beginning of each chapter) particularly relevant.

\section{Summary}

- Future demographic developments are likely to have a significant impact on the available workforce for future factories.

- A probable scenario is that there will be a larger proportion of elderly people in many Westernized economies, alongside a shortage of skilled, young workers willing to choose a career in the production sector.

- The persistent problem with high youth unemployment in Europe contrasts with the demographics problem, but can be explained with the skills gap concept and the fact that unemployment can be defined in many different ways.

- Future factories must address the challenges of becoming more attractive workplaces, as well as adapting to the needs of an aging workforce.

- Sustainability as a whole is commonly defined as having three tracks: economical, environmental and social sustainability.

- The history of sustainable development starts in the late 1980s and has prior to now had a greater focus on the environmental and economic sides.

- The current demographic developments demand that production companies start to focus more on the overlap between economical and social sustainability.

- Social sustainability issues can be analysed and solved on the individual, industrial and societal levels. Ignoring any of these levels may lead to unbalanced solutions.

\subsection{References}

Accenture (2013). International Women's Day 2013 Defining Success 2013 Global Research Results. [Online] Available from: http://www.accenture.com/SiteCollectionDocuments/PDF/ AccentureIWD-2013-Research-Deck-022013.pdf [Accessed 13 Jan 2014].

Austin R. D. \& Sonne, T. (2014). The Case for Hiring “Outlier” Employees. Weblog. [Online] Available from: http://blogs.hbr.org/2014/01/the-case-for-hiring-outlier-employees/ [Accessed 13 Jan 2014].

Beech, H. (2 Dec 2013). Why China Needs More Children. TIME Magazine. [Online] Available from: http://content.time.com/time/subscriber/article/0,33009,2158110-2,00.html [Accessed 13 Jan 2014]. 
Berlin, C., Dedering, C., Jónsdóttir, G. R. \& Stahre, J. (2013). Social sustainability challenges for European manufacturing industry: attract, recruit and sustain. In IFIP International Conference on Advances in Production Management Systems (pp. 78-85). Berlin, Heidelberg: Springer.

Carroll, A. B. (1979). A Three-Dimensional Conceptual Model of Corporate Performance. The Academy of Management Review, 4(4):497-505

Colantonio, A. (2009). Social Sustainability: Linking Research to Policy and Practice. [Lecture] Oxford Brookes University, 26-28 May.

Dobbs, R., Madgavkar, A., Barton, D., Labaye, E., Manyika, J., Roxburgh, C., Lund, S. \& Madhav, S. (2012). The World at Work: Jobs, Pay and Skills for 3.5 billion people. McKinsey Global Institute [Online] Available from: http://www.mckinsey.com/insights/employment_and_growth/the_ world_at_work [Accessed 13 Jan 2014].

Elkington, J. (1998). Cannibals with Forks: The Triple Bottom Line of 21st Century Business. Gabriola Island, BC Stony Creek, CT: New Society Publishers. ISBN: 0865713928

European Commission. (2014). Research and Innovation Participant Portal: Call for Factories of the Future. [Online] Available from: http://ec.europa.eu/research/participants/portal4/desktop/en/ opportunities/h2020/topics/2183-fof-04-2014.html [Accessed 17 Jan 2014].

Eurostat. (2012). Population on 1 January by five years age groups and sex. [Online] Available from: http://appsso.eurostat.ec.europa.eu/nui/show.do?dataset=demo_pjangroup\&lang=en [Accessed 15 Jan 2014].

Foresight. (2013). The Future of Manufacturing: A new era of opportunity and challenge for the UK. Project report. The Government Office for Science, London.

Halkos, G. \& Bousinakis, D. (2010). The effect of stress and satisfaction on productivity. International Journal of Productivity and Performance Management, 59(5):415-431.

Healy, T. \& Côté, S. (2001). The Well-Being of Nations: The Role of Human and Social Capital. Education and Skills. Organisation for Economic Cooperation and Development, 2 rue Andre Pascal, F-75775 Paris Cedex 16, France.

Holme, R. \& Watts, P. (2000). Corporate Social Responsibility: Making good business sense. World Business Council for Sustainable Development [Online] Available from: http://research.dnv.com/ csr/PW_Tools/PWD/1/00/L/1-00-L-2001-01-0/lib2001/WBCSD_Making_Good_Business_ Sense.pdf [Accessed 15 Jan 2014].

ISO. (2010). ISO 26000. Social responsibility. [Online] Available from: http://www.iso.org/iso/ home/ standards/iso26000.htm [Accessed 15 Jan 2014].

Karazman, R., Kloimüller, I., Geissler, H. \& Karazman-Morawetz, I. (2000). Effects of ergonomic and health training on work interest, work ability and health in elderly public urban transport drivers. International Journal of Industrial Ergonomics, 25(5):503-511. ISSN 0169-8141

Make In India. (2015). Make In India. [Online] Available from: http://www.makeinindia.com/home [Accessed 20 Nov 2015].

Mourshed, M., Patel, J. \& Suder, K. (2014) Education to Employment: Getting Europe's Youth into Work. McKinsey Center for Government. [Online: Report] Available from: http://www.mckinsey. com/Insights/Social_Sector/Converting_education_to_employment_in_Europe?cid=other-emlalt-mip-mck-oth-1401 [Accessed 13 Jan 2014].

NASA. (1996). Sustainable Development Indicator (SDI) Group SDI Inventory, Organized by Issue Working Draft, Version 3, October 8, 1996. [Online] Available from: http://www.hq.nasa.gov/ iwgsdi/ISS_SDI_Equity.html\#Social\%20Equity [Accessed 16 Jan 2014]. 
OECD. (2014). Glossary of statistical terms. [Online] Available from: http://stats.oecd.org/ glossary/ [Accessed 13 Jan 2014].

Richter, G., Bode, S. \& Köper, B. (2014). Demographic Changes in the Working World. [Online] Available from: http://www.baua.de/en/Publications/Focus/article30.pdf?_blob=publication File\&v $=4$ [Accessed 15 Sept 2016].

SO SMART. (2014). SO SMART Eco System.[Online] Available from: http://sosmarteu.eu/ [Accessed 20 Nov 2015].

UNEP/Setac. (2009). Guidelines for Social Life Cycle Assessment of Products. United Nations Environment Programme. [Online] Available from: http://www.unep.fr/shared/publications/pdf/ DTIx1164xPA-guidelines_sLCA.pdf [Accessed 17 Jan 2014].

United States Department of Commerce. (2012). Fact sheet: Make it in America Challenge. [Online] Available from: http://www.commerce.gov/news/fact-sheets/2012/09/25/fact-sheet-make-itamerica-challenge [Accessed 13 Jan 2014].

Vallance, S., Perkins H. C. \& Dixon J. E. (2011). What is social sustainability? A clarification of concepts. Geoforum, 42(3), June 2011:342-348. ISSN 0016-7185

WCED. (1987). World Commission on Environment and Development (WCED), Our Common Future. Oxford: Oxford University Press.

Westkämper, Engelbert. (2014). Towards the Re-industrialization of Europe: A Concept for Manufacturing for 2030, Springer-Verlag Berlin Heidelberg. ISBN 978-3-642-38502-5.

\section{Bibliography}

Docherty, P., Kira, M. \& Shani, A. (2009). Creating Sustainable Work Systems: Developing Social Sustainability. New York, NY: Routledge.

IISD. (2012). Sustainable Development Timeline. [Online] Available from: www.iisd.org/pdf/2012/ sd_timeline_2012.pdf [Accessed 3 March 2013].

Rosling. (n.d.) Gapminder.org. [Online] Available from: http://www.gapminder.org/ [Accessed 19 Jan 2014]. 
